\title{
Cataloguing and Classification Education (CCE) and training in Library and Information Science/Studies departments in South Africa
}

\author{
Lyudmila Ocholla $^{1}$ \\ Ochollal@unizulu.ac.za \\ ORCID Id: http://orcid.org/0000-0003-3753-8659 \\ Dennis Ocholla ${ }^{2}$ \\ Ochollad@unizulu.ac.za \\ ORCID Id: http://orcid.org/0000-0003-3860-1736
}

\begin{abstract}
Received: 11 February 2014
Accepted: 01 June 2014

Recent reports complain about the lack of cataloguers in South Africa to support Library and Information Services. The purpose of this study is to investigate the nature, level, status and challenges of teaching cataloguing and classification in LIS schools in South Africa. Qualitative and quantitative methods, through a survey and content analysis, were employed in this study. All twelve LIS/IS departments in South Africa were targeted. Within these departments, the main sources of research data were the department heads and/or lecturers teaching cataloguing and classification, as well as the course outlines or study guides of cataloguing and classification modules or courses. Survey data was collected through interviews and largely through questionnaires that were emailed to the respondents in the various LIS departments. Content analysis was employed for curriculum and syllabus analysis. Most respondents agreed that CCE should be offered in its current form and some uniformity in the titling of courses should be achieved. While most CCE challenges are not new, intervention is still required, particularly with regards to Resource Description and Access (RDA) which must be addressed by LIS schools as soon as possible. This study informs cataloguing and classification education in South Africa, and perhaps elsewhere, by providing baseline information for the planning, teaching, marketing and recruiting of graduates qualified in the two research domains.
\end{abstract}

Keywords: South Africa, Cataloguing and Classification Education (CCE), organisation of information, information organisation, Library and Information schools, LIS schools, library schools

\section{Introduction and background}

Cataloguing and classification as a subject area in universities has been dramatically affected by rapid changes in Library and Information Science (LIS) or iSchool education (see Wiegand 1999, Blankson-Hemans \& Hibberd 2004, Gerolimos 2009, Ivey 2009, Al Hiji 2013). The most recent reports, largely from the USA (Blankson-Hemans \& Hibberd 2004, Hill 2004, Davis 2008, Bowen-Chang \& Hosien 2009, Pattuelli 2010, Shongwe \& Ocholla 2011), confirm a shortage of cataloguers in libraries and information centres and strongly support their education and training. This shortage would explain why LIS schools in South Africa are increasingly challenged and encouraged to produce more cataloguers for the library market.

Bowen-Chang and Hosein (2009) suggest that the infusion of technological innovations into libraries and the changing role of cataloguers have unearthed a new dimension in the sphere of cataloguing that influences its teaching as well. Thus, notes Hill (2004), cataloguing education has changed and the on-going process of transformation is taking it in different and unforeseen directions. The changes brought about by the developments in Information and Communication Technologies (ICT) mean that Cataloguing and Classification Education (CCE) has to go beyond traditional bibliographic control. It should enable students to make information management decisions, as well as to analyse, synthesise, and evaluate publications of different types and formats. Many authors (for example, Gorman 2002, Cloete, Snyman \& Cronje 2003, Gathegi \& Mwathi 2007, Bowen-Chang \& Hosein 2009, Shongwe and Ocholla 2011) support the teaching of cataloguing and classification for LIS education and see it as an important component of the organisation of recorded knowledge. Gorman is critical of those whom he calls "enemies of cataloguing". He argues that "enemies of cataloguing" today include ill-informed administrators, information scientists in library schools, and those who think that alternatives to vocabulary control and bibliographic architecture - such as Google - are better and cheaper than cataloguing (Gorman 2002: 1). III-informed library administrators, in Gorman's view (2002: 2), normally lack a technical processing background and do not appreciate the backbone and principles of OCLC that largely depend on effective local (library level), national and international bibliographical control. Thus, Gorman asserts, "those administrators believe that OCLC records grow on trees and their libraries can safely dispense with original cataloguers to rely on ill-paid staff to pick the fruit of the OCLC trees and construct incoherent catalogues of increasingly less use to their users" (Gorman 2002: 2). "III-informed library

1. Lyudmila Ocholla is a Senior Librarian at the University of Zululand Library Services.

2. Professor Dennis Ocholla is Head of the Department of Information Studies, University of Zululand. 
administrators" do not value cataloguing, do not maintain or support a cataloguing department in their libraries, and would hardly support a sound cataloguing education (Gorman 2002: 2). As Cerbo (2011: 323) explains, "many are concerned that library administrators believe budgetary resources would be better spent on other matters, leaving library users with an over-abundance of electronic information to muddle through on their own". Information scientists in library schools are opponents to cataloguing education as well. Gorman (2002: 2) reasons that, information scientists who know nothing about librarianship pursue their own narrow teaching and research interests and claim to produce information professionals who can work within or without libraries. Those who advocate for alternatives to bibliographic control are highly technocentric or "metadatalogists", as Gorman calls them, and strongly support metadata formats largely based on Dublin Core standards. These advocates ignore MARC format - standard for holding bibliographic data - and Resource Description and Access (RDA) which is due to replace AACR2.These formats are all technologically grounded for einformation retrieval and organising recorded knowledge.

South Africa has twenty-five universities, twelve of which have LIS schools or Information/Library schools. The schools have different names: the University of Pretoria (UP) - Department of Information Science; University of Cape Town (UCT) - Library and Information Studies Centre; University of the Western Cape (UWC) - Department of Library and Information Science; University of Fort Hare (UFH) - Department of Library and Information Science; Durban University of Technology (DUT) - Department of Information and Corporate Management; University of Kwa-Zulu Natal (UKZN) - Information Studies Programme; University of Zululand (UZ) - Department of Information Studies; University of South Africa (UNISA) - Department of Information Science; University of Johannesburg (UJ) - Department of Information and Knowledge Management; University of Stellenbosch (SU) - Department of Information and Knowledge Management; University of Limpopo (UL) - Department of Communication, Information and Media Studies (Information Studies programmes belong here); and the Walter Sisulu University (WSU) - Department of Library and Information Science. Our survey observed that cataloguing and classification is currently being offered at UCT, UL, UKZN, UNISA, UFH, UWC, DUT and UZ. Others do not teach it at all (UJ and US) or suspended teaching because of a lack of students in the relevant qualification programme (UP) and suspended student intake in the LIS Department (WSU).

This study investigates the nature, levels, status and challenges of teaching cataloguing and classification in LIS schools in South Africa. The study addresses the following research questions: Is it still necessary to teach cataloguing and classification in LIS schools? Who should study or be taught cataloguing and classification? At what levels are the courses being offered? What is the content of the curriculum in terms of modules, courses and content or units being taught? How are the courses being taught in terms of the methods used? What are the challenges and opportunities arising from teaching cataloguing and classification?

\section{Methodology}

Qualitative and quantitative methods, through a survey and content analysis, were employed in this study. This approach was motivated by the number of recent studies of this nature that successfully used mixed research methods (Ngulube 2010). In South Africa, examples include studies by Ocholla (2009) and Ndwandwe, Ocholla and Dube (2009), which focused on information ethics education in South Africa and Africa respectively, and a study by Chipeta, Jacobs and Mostert (2009), which focused on information literacy education. All twelve LIS/IS departments in South Africa were targeted. Within these departments, the main sources of information were the department heads and/or lecturers teaching cataloguing and classification, as well as the course outlines or study guides of cataloguing and classification modules or courses. Survey data was collected through interviews and largely through questionnaires that were emailed to the respondents in the various LIS departments in 2010. Content analysis was employed for curriculum and syllabus analysis. Data has been updated and verified. The authors of this paper were able to access most of the cataloguing and classification syllabi, which proved useful in confirming interview and questionnaire responses. As part of content analysis, the analyses of course content and description or syllabi seemed to be quite common in related studies conducted in the USA (for example, Davis 2008: 188, Pattuelli 2010: 2). The research instruments were very similar to those used in the studies referred to above, but with some modifications. During two months of the second half of 2010 , visits were paid to the various departments and access gained to their curricula and syllabi for the two courses. In total, information was collected from eight departments that were teaching cataloguing and classification. Although a follow up to this study was done in 2012 and 2013, largely by reviewing the curricular of some of the LIS schools, no major changes in CCE in the targeted institutions has been found that would affect this report. One change has been at UCT where RDA cataloguing and metadata rather than AACR2 has been introduced; the Postgraduate Diploma in Library and Information Studies (PGDipLIS) is currently offered at HEQSF level 8; and Bibl. (Hons) is no longer offered as PGDipLIS students can now proceed to Masters. Planning for RDA teaching in other LIS schools is underway.

\section{Results and discussions}

The findings are organised under seven sub-headings below.

\subsection{Is it still necessary to teach cataloguing and classification in LIS schools?}

Cataloguing and classification still belong to the core competency and activities of librarians, as reflected in the American Library Association (ALA) core competencies of librarianship which was approved and adopted as policy by the ALA Council in January 2009 (ALA 2009), and is widely taught in LIS schools in Africa. Gorman (2002: 2) asserts that "we should teach cataloguing and classification because it is essential that those who wish to be librarians (not just those who wish to be cataloguers) understand the way in which recorded knowledge and information is organised for retrieval". 
Thus, it is nearly impossible to function effectively as a librarian without sound knowledge of library collection, how the resources are organised, where to find them, and how to use them. In other words, "if you cannot think like a cataloguer, you cannot think like a librarian and, therefore, cannot deliver effective library services" (Gorman 2002: 11). Similarly, Cerbo (2011: 326) asserts: "an excellent librarian - this is what catalogers are and will continue to be in the future". Cerbo (2011: 234) illustrates her view with a list of several areas where skills of cataloguers are needed, such as: development of online digital repositories, development of metadata for digital repositories and accommodation of new developments in content management such as RDA. As a result, the new cataloguer roles or job titles, adds Cerbo, have changed rapidly to include: Digital Imitative Librarian, E-Resource Librarian, Library Information Technologist and Metadata Librarian (Cerbo 2011: 325).

Responses to the survey were received from all eight universities teaching cataloguing and classification, who all agree that cataloguing and classification should be taught in LIS education. They consider cataloguing and classification to be a core LIS course, the backbone of a librarianship professional qualification and a course that supports the knowledge of library information and reference services. They find cataloguing and classification extremely useful for the critical analysis and synthesis of a library collection for effective information services, and essential for the organisation of recorded knowledge in libraries.

\subsection{Who should study or be taught cataloguing and classification?}

This area raised different opinions. Information and management schools do not teach cataloguing and classification because it is irrelevant to their qualification programmes (UJ and US). It is also not offered where non-professional LIS qualifications are offered, such as undergraduate qualifications or degrees in publishing, records management, multimedia, and information science (UP). However, the general consensus is that all future professional librarians should be taught cataloguing and classification, with a few respondents suggesting that all information studies/science graduates should be offered the courses because it is relevant in information service provision of all kinds. The scope of cataloguing and classification education is quite wide and diverse. Davis (2008), referring to cataloguing education in the USA in general, and Miller et al. (2012), referring to the University of Wisconsin-Milwaukee in particular, identify the following related courses: Organization of Information; Metadata; Indexing and Abstracting; Controlled Vocabulary and Thesaurus; Information Architecture; Classification Theory; Comparative Bibliography; Social and Cultural Issues in Information Organization; Linked Data for Libraries; Semantic Web and Web 2.0; RDF; Ontologies and the Semantic Web.

While the two Information Management schools in South Africa (UJ and SU) may not call what they teach "cataloguing" or "classification", they do, in fact, teach the broad fields of cataloguing and classification as identified by Miller et al. (2012) and Davis (2008).

\subsection{At what levels are the courses being offered?}

Ocholla and Bothma (2007: 158) identify five categories of LIS education: the nature and type of the qualification programme offered (e.g. Bachelor or Master's degree); the duration and credit requirements for a qualification (e.g. three or four years); the academic levels of the qualification (e.g. undergraduate or postgraduate); the mode of instruction (contact or distance); and the orientation of the LIS School (e.g. vocational or general education). All of these categories have a bearing on the levels and depth of cataloguing and classification teaching, learning and research. This study shows that cataloguing and classification is mainly offered to senior students, normally from their second year of university study and mostly to third- and fourth-year students. There are cases where the courses are offered from the first year in a university, although these normally only cover the basics of cataloguing and classification. Offering cataloguing and classification from basic to advanced levels is not unusual as reflected in studies by Davis (2008), Miller et al. (2012) and Gorman (2002), referring to the USA, and Gathegi and Mwangi (2007), referring to Kenyatta University in Kenya where LIS education is offered at postgraduate level. The postgraduate level model for LIS education in South Africa is offered at UCT and UKZN. The content is largely similar to the content offered to undergraduate bachelor students elsewhere because postgraduate students at UCT and UKZN generally take this course for the first time in their careers. Admission to postgraduate LIS education at UCT and UKZN largely requires that the candidate possesses a bachelor's degree.

\subsection{What is the content of the curriculum in terms of modules, courses and content or units being taught?}

We note that cataloguing and classification courses are taught separately and bear a variety of course titles. Such titles (the authors picked these from the curricula/syllabi from the LIS Schools that were available to them) include, in no particular order: Information Retrieval 1, Information Retrieval 2, Information Retrieval 4; Cataloguing, Classification, Cataloguing and Classification, Organisation of Knowledge; Descriptive Cataloguing; Subject Analysis; Bibliographic Control, Basic Descriptive Cataloguing and Classification; Subject Organization; Theory of Cataloguing and Classification; Practical Cataloguing; Computerised Cataloguing; Information Retrieval (Classification); Databases and Database Construction (Cataloguing); Basic Cataloguing; Basic Classification; Indexing and Thesaurus Construction; Special Cataloguing and Advanced Classification. In most cases, these courses are taught for one semester and some courses are offered at either basic or junior levels, while others are offered at an advanced level. In the latter case, there would be a prerequisite for having a basic level of knowledge in the course in order to enroll for a senior level (advanced) course. The authors observed through their experience in the LIS education sector, that course titling could be influenced not only 
by content, but increasingly by the need to attract and retain students. They also noticed, in the curricula analysed, that there are cases where cataloguing and classification are taught within indexing, thesaurus construction and abstracting courses, when indeed these subjects belong in the CCE cluster (see also Miller et al. 2012).

The content of the cataloguing and classification courses falls within the following categories: AACR2; abstracting; authority control; bibliographic control; bibliographic description; cataloguing: theory, process, tools, manual, computerised, online; classification: theory, history, schemes, process, policies; DDC; descriptive cataloguing; Dublin core; indexing; information retrieval; LCSH; library catalogues; MARC 21; metadata; subject organisation and access; and thesaurus construction.

A survey of cataloguing education in the USA by Davis (2008) divided cataloguing education into eight areas:

1. Organisation, focusing on general principles of bibliographic control and basic knowledge of information organisation;

2. Basic cataloguing, focusing on the introduction to knowledge and related skills (for example, AACR2, MARC, LC, DDC);

3. Advanced cataloguing (AC), focusing on details, complex aspects and practicals;

4. Subject analysis, focusing on subject cataloguing and classification;

5. Indexing and abstracting;

6. Metadata schema and applications;

7. Serials, focusing on bibliographic control of serials;

8. Other foci are on issues and topics not covered in any of the seven categories.

Except for basic cataloguing or organisation of knowledge (see Patuelli 2010), the other six areas could be categorised under "advanced cataloguing". Similar to Patuelli (2010), who analyses introductory courses in cataloguing in the USA, Davis's study concluded that "LIS programs are continuing to offer and require introductory courses in cataloguing and bibliographic control, they are relying more heavily on these introductory courses to provide the bulk of cataloguing education" (Davis 2008: 182).

Unlike the South African scenario, where hands-on cataloguing is taught alongside theory at all levels, except at the University of South Africa (distance learning), practical cataloguing does not seem to be offered at basic levels at the USA LIS schools reviewed by Davis. Also, many LIS schools teach most of the eight content areas mentioned by Davis in one semester (15 weeks) or two semester courses. There is a strong support for CCE in both theory and practice in the reviewed literature (for example, Davis 2008, Hsuieh-Yee 2008, Hudon 2010). Interestingly, Hill and Intner, cited by Davis (2008: 195), caution that "when a library school curriculum provides no opportunity for every student to perform a certain amount of actual cataloguing, many who might have loved the work will never apply for cataloguing positions".

\subsection{How are the courses being taught in terms of the methods used?}

There is no single method recommended for CCE as multiple methods highly enrich it (Hudon 2010, Miller et al. 2012, Normore 2013, Al Hijji 2013). Normore (2013: 177), citing related studies, identifies four possible categories of CCE. The first category (citing Hider) is "drill and practice", based on repetition until the learning outcome is achieved. Second (citing Gagne) is "concept learning" or "rule learning" which focuses on the identification of major categories and the correct use of rules and standards provided in controlled vocabularies (e.g. AACR2, RDA, LC, DDC). The third category (citing Sheilla) focuses on "decision making". Lastly (from Olson) is "critical thinking". The use of cognitive maps and wayfinding is also highly recommended (Normore 2013: 178). While a variety of methods are suggested for CCE (Miller et al. 2012, Al Hijji 2013), teaching both theory and practice is highly recommended. Normore (2013: 172) argues that "teaching cataloguing requires instructors to present and integrate information about the variety and complexity of the field while providing adequate theoretical foundation for practice" and suggests a problem-solving approach called "wayfinding" as one of the methods to use. Miller et al. (2012), as well, provide innovative ways of teaching cataloguing and classification through online cataloguing education at the University of Wisconsin-Milwaukee.

In this study, it was revealed that cataloguing courses are largely taught in South Africa through lectures and class practicals. Other methods include group discussions, online exercises, workshops, seminars, projects, practical assignments, case studies, and quizzes. With the exception of UZ, UL, and UKZN, where these courses are offered by library staff (and a few lecturers), the courses are taught by LIS academics.

\subsection{What are the challenges and opportunities arising from teaching the course?}

A number of challenges were identified by the respondents. Generally, students are said to demonstrate low levels of competence and to lack general knowledge and analytical skills. Some students require a great deal of individual attention, there is not enough fieldwork or practicals where students can test their knowledge, and there are not enough cataloguing tools for online cataloguing. One respondent stated that one semester allocated for teaching cataloguing or classification is not adequate and that students do not always order tools such as AACR2, DDC and LCSH reference books, which are needed for practical work, from the library. Other problems, noted in particular from one urban university, stem from universities' assessment rules and regulations: a two-hour examination paper for theory and practical for the assessment of students taking the modules is simply not enough. There were also complaints about the use of practicals only, which also limits the acquisition of knowledge and skills for online cataloguing. In some cases, the 
size of the class (over 100 students in one surveyed university) is too large to maintain high standards of teaching and learning.

Other challenges are the need for continuous training for lecturers in order to keep up to date, as well as staffing problems: there are only three staff members in one of the surveyed LIS departments. It was stressed that classification in particular is a very challenging course that demands adequate preparation and students' learning competence. Equally disturbing, in some cases, is the description of students' lack of reading interest, which makes learning more difficult. In addition, expensive cataloguing tools, lack of mathematical skills, language or communication problems for students whose mother tongue is not English, cognitive problems of weaker students, and lack of general knowledge were noted.

Future opportunities depend on whether or not there is a future for cataloguing and classification. Although in some countries cataloguing has been marginalised by the library, administrators and information scientists, LIS schools in the USA seem to be re-considering the marginalisation of these courses (Cerbo 2011). Cataloguing and classification education has begun to feature strongly in the curriculum of some prominent LIS Schools in the country (Hudon 2010, Miller et al. 2012, Veitch et al. 2013). New requirements of technology (Hsieh-Yee 2008: 103) make CCE even more necessary.

\subsection{What suggestions can be made for the future?}

Findings from the survey suggest that, in order for CCE to be improved, the challenges identified above need to be addressed. Small group practical sessions are necessary and these require staffing and adequate time allocation in the timetable. Individual consultation times for lecturers to interact with students need to be regularised where they do not occur. Modern libraries are increasingly computerised, demanding computerised or web-based information processing and related retrieval knowledge and skills from LIS graduates. It was found that manual cataloguing predominates - only a few LIS schools support web-based cataloguing. A combination of both computerised and manual cataloguing is recommended by a respondent from one LIS school. Other suggestions from respondents included: making copies of pages relevant to cataloguing (for example, the title page or table of contents of items) for practical teaching in class; teaching the latest cataloguing changes theoretically and, where possible, showing students using the lecturer's edition, which would be the latest edition, unavailable to many students; enabling students to practice using the university library's online system; making cataloguing tools available to students; reducing the size of classes; involving LIS schools in student selection; and employing more members of staff. There was the suggestion that lecturers should become members of the Interest Group for Bibliographic Standards (IGBIS) and should participate with cataloguers in all continuous training in order to be up-to-date with current developments.

\section{Conclusion}

While all the surveyed departments teach cataloguing and classification, the degree, level, depth and breadth of the education they offer are not uniform and depend on variables such as the levels of the course, the objectives of the course, and the outcomes required. There are different opinions on whether cataloguing and classification should still be taught in LIS schools. The authors, however, support the teaching of cataloguing and classification because they consider it to be an essential component of LIS education, particularly for future librarians and information service providers in South Africa. Given some of the concerns raised by the respondents, cataloguing and classification should be taught at senior levels of university education, preferably from second year. In the authors' opinion, students need to be introduced to the concepts and background of Information Science, librarianship, information literacy, information collection and information sources before they tackle cataloguing and classification.

The titling of LIS courses in the changing information environment is of particular importance to attract and retain students. As noted in a tracer study of UZ graduates (Shongwe and Ocholla 2011), in the Bachelor of Arts Information Science programme that was aimed at the broad information service market, cataloguing and classification were initially not included for fear of losing students who would not necessarily work in libraries and who were interested in a strong IT component in their IS education. However, supported by evidence from the study, when the students graduated, most of them found jobs in libraries where their lack of cataloguing and classification knowledge became a problem. The Department of Information Studies at the University of Zululand had to subsequently introduce cataloguing and classification in the courses "Information Retrieval 1"(largely cataloguing) and "Information Retrieval 2" (largely classification) to enable students to gain the knowledge they might need in the market, but, at the same time, not chase away potential students. The courses are known by their traditional names (e.g. cataloguing) in the four-year librarianship qualification programmes on offer at the University of Zululand.

While course titles are a dilemma faced by most LIS schools in South Africa, ideally course titling should reflect the content being taught and should not be overly swayed by the perceptions of potential students. We have noted more similarities than differences in the course content on offer in LIS schools in the country. Regarding teaching methods, lectures and practicals are predominant, as they are an important component of effective teaching. However, fieldwork or experiential learning, which is also essential for teaching and learning, was not mentioned. At the University of Zululand, fieldwork has a positive impact on students' attitude towards cataloguing and classification, resulting in more commitment and a better understanding of the role and applications of cataloguing and of the cataloguer's profession as a whole.

Although the challenges identified for teaching cataloguing and classification are not necessarily new, they require intervention through short, medium and long term plans that have to be urgently introduced by LIS schools in the country. Interventions may include offering short courses and curriculum revision to incorporate new and emerging trends and needs. The introduction and integration of Resource Description and Access (RDA) in the teaching of cataloguing in 
South Africa comes with challenges that have to be addressed in the near future. This is, perhaps, the right time for reviewing the curriculum for cataloguing by all eight LIS schools involved in CCE. Taking into consideration the different landscape of South African libraries and having a desire to accommodate all stakeholders (some school libraries do not have electricity, for example; some public libraries do not have adequate computer facilities, while academic libraries are usually well-equipped in cataloguing and classification needs), each LIS school should reconsider how to proceed with CCE, deciding, for example, whether to teach AACR2 or RDA, or both and at what levels.? They should also consider the growing expectations from employers. As Ivey (2009) notes, "although library science programs will need to train students in the new cataloguing tools, they must also prepare them to be effective teachers and researchers." He continues: "The cataloguer of the future must be visible, be a good communicator, and be capable of performing many different library functions."

This study aspires to inform CCE in South Africa and perhaps elsewhere by providing baseline information for the teaching, marketing and recruitment of graduates who are qualified in this important LIS education subject.

\section{References}

American Library Association. 2009. Core competencies of librarianship. [Online]. http://www.ala.org/educationcareers/sites/ala.org.educationcareers/files/content/careers/corecomp/corecompetences /finalcorecompstat09.pdf.

Al Hijji, K.Z. 2013. Cataloguing and classification education in Gulf Cooperation Council (GCC) countries. Cataloging and Classification Quarterly, 50(4): 276-292.

Blankson-Hemans, L. and Hibberd, B.J. 2004. An assessment of LIS curricula and the field of practice in the commercial sector. New Library World, 105(7/8): 269-280.

Bowen-Chang, P. \& Hosein, Y. 2009. Cataloguing training at the University of the West Indies, St Augustine. Library Review, 58(2): 97-108.

Cerbo, M. A. 2011. Is there a future for library catalogers? Cataloging and Classification Quarterly, 49(4): $323-327$.

Chipeta, G., Jacobs, D. \& Mostert, B.J. 2009. Teaching and learning of information literacy in institutions of higher learning in KwaZulu-Natal and Malawi. South African Journal of Libraries and Information Science, $75(1): 46$-57.

Cloete, L.M., Snyman, R. \& Cronje, J.C. 2003. Training cataloguing students using a mix of media and technologies. Aslib Proceedings, 55(4): 223-233.

Davis, J.M. 2008. A survey of cataloging education: are library schools listening? Cataloging and Classification Quarterly, 46(2): 182-200.

Gathegi, J.N. \& Mwathi, P.G. 2007. Creating a needs-response LIS curriculum in a developing country: A case study from Kenya. International Information and Library Review, 39: 134-144

Gerolimos, M. 2009. Skills development through library and information science education. Library Review, 58(7): 527540.

Gorman, M. 2002. Why teach cataloguing and classification? Cataloguing and Classification Quarterly, 34(1-2): 1-13.

Hsieh-Yee, I. 2008. Educating professionals in a changing information environment. Journal of Education for Library and Information Science, 49(2): 93-106.

Hill, J.S. 2004. Education and training of cataloguers: obsolete? Disappeared? Transformed? Part II. Technicalities, 24(12): 10-15.

Hudon, M. 2010. Teaching classification, 1990 -2010. Cataloging and Classification Quarterly, 48(1): 64-82.

Ivey, R.T. 2009. Perceptions of the future of cataloging : is the sky really falling? Cataloguing \& Classification Quarterly, 47: 464-482.

Miller, S.J., Lee, H., Olson, H.A. Smiraglia, R.P. 2012. Online cataloguing education at the University of WisconsinMilwaukee. Cataloging and Classification Quarterly, 50(2-30: 110 -126.

Ndwandwe S., Ocholla, D. \& Dube, L .2009. Information ethics education in library and information science departments/ schools in South Africa. Mousaion, 27(2): 75-88.

Ngulube, Patrick.2010. Mapping mixed methods research in library and information science journals in Sub-Saharan Africa 2004 - 2008. International Information and Library Review, 42(4): 252-261.

Normore, L.F. 2013. "Here be dragons": a wayfinding approach to teaching cataloguing. Cataloging and Classification Quarterly, 50(2-3): 172-188.

Ocholla, D.N. 2009. Information ethics education in Africa: where do we stand? International Information and Library Review, 41(2): 79-88.

Ocholla, D.N. \& Bothma, T. 2007. Library and information education and training in South Africa. In T. Bothma, P. Underwood \& P. Ngulube, Eds. Libraries for the future: progress and development of South African libraries. Pretoria, LIASA. 149-168.

Ocholla, D.N., Ocholla. L., Olson, H.A., Glover. J.R. and Guimarães, J.A. 2012. Cataloging and classification education (CCE) and training in library and information science/studies in South Africa, Brazil and the USA. [Online]. http://conference.ifla.org/past-wlic/2012/105-ocholla-en.pdf (15 January 2014).

Pattuelli, C.M. 2010. Knowledge organisation landscape: A content analysis of introductory courses. Journal of Information Science, 36(6): 812-822.

Shongwe, M. and Ocholla. D. 2011. A tracer study of LIS graduates at the University of Zululand, 2000 -2009. Mousaion, 29(2): 227-238. 
Veitch, M., Greenberg, J., Keizer, C. and Gunther, W. 2013. The UNC-Chapel Hill RDA boot camp: preparing LIS students for emerging topics in cataloging and metadata. Cataloging and Classification Quarterly, 51(4): 343-364.

Wiegand, W.A. 1999. Core curriculum: a white paper. Congress on Professional Education: Issues in Library and Information Studies Education. American Library Association.

Shorter versions of this paper were presented at the Crimea Conference, Sudak, Ukraine, $4-12$ June 2011 and IFLA Conference, Helsinki 11-17 August 2012. The University of Zululand Research Office/Committee is acknowledged for funding this project. 